\title{
Boomjuridischtijdschriften
}

DOI: $10.5553 /$ TCC/221195072017007001001

\section{Superdiversiteit, wijken van aankomst en conflicten. Een inleiding}

\author{
prof. dr. Richard Staring en Dr. Bas van Stokkom
}

\begin{abstract}
Aanbevolen citeerwijze bij dit artikel
prof. dr. Richard Staring en Dr. Bas van Stokkom. (2017). Superdiversiteit, wijken van aankomst en conflicten. Een inleiding. Tïjschrift over Cultuur \& Criminaliteit (7) 1, .
\end{abstract}

\section{Superdiversiteit: een omschrijving}

Veel grote steden in Europa hebben te maken met een aanhoudend grote instroom van migranten uit vele werelddelen. Sommige stadsdelen fungeren als 'wijken van aankomst' die gekenmerkt worden door een veelheid aan etnische groepen, verblijfsstatussen, talen, culturen en religies. Jan Blommaert (2011) spreekt in dit verband van een 'extreme versnippering' in de achtergronden van migranten. De autochtone bevolking - die overigens als de uitkomst van eerdere migratiebewegingen gezien kan worden - werd gaandeweg zelf een minderheid. Inmiddels heeft zich een omvangrijke groep academici laten inspireren door het concept 'superdiversiteit', waarbij sommigen superdiversiteit als een onmiskenbare realiteit beschouwen en anderen het bekritiseren (zie bijvoorbeeld Blommaert, 2011; Geldof, in dit nummer).

De Duitse socioloog Steven Vertovec introduceerde het concept superdiversiteit een decennium geleden in zijn artikel 'Super-diversity and its implications' (2007). Het loont de moeite de inhoudelijke beschrijving van superdiversiteit hier weer te geven, evenals het 'actieplan' voor beleidsmakers en academici dat volgens Vertovec logischerwijze hieruit voortvloeit.

"By invoking "super-diversity" I wish, firstly, to underscore the fact that in addition to more people now migrating from more places, significant new conjunctions and interactions of variables have arisen through patterns of immigration to the UK over the past decade; their outcomes surpass the ways - in public discourse, policy debates and academic literature - that we usually understand diversity in Britain. Secondly, then, the article serves as a call, or at 
variables when considering the nature of various "communities", their composition, trajectories, interactions and public service needs.' (2007: 1025)

In de visie van Vertovec is sinds het begin van het tweede millennium migratie fundamenteel van karakter veranderd, doordat een toenemende diversiteit aan herkomstlanden interacteert met een grotere diversiteit aan leefstijlen en dat in een omgeving waarin aan burgerschap meer belang wordt gehecht en onrechtmatig verblijf van migranten wordt geproblematiseerd. Deze nieuwe realiteit zou ook consequenties moeten hebben voor het werk van politici, beleidsmakers en academici. Zij gaan volgens Vertovec nog te veel uit van een multiculturele samenleving, maar zouden zich juist veel meer rekenschap moeten geven van hoe in stedelijke contexten uiteenlopende beroepen, inkomensgroepen, generaties, talen, verblijfsstatussen en religies met elkaar interacteren en een ander gezicht aan de stedelijke omgeving geven.
'Whatever we choose to call it, there is much to be gained by a multidimensional perspective on diversity, both in terms of moving beyond "the ethnic group as either the unit of analysis or sole object of study" (Glick Schiller et al., 2006: 613) and by appreciating the coalescence of factors which condition people's lives. (Vertovec, 2007: 1026)'

Het verwisselen van een dergelijke 'etnische bril' voor een perspectief waarin superdiversiteit centraal staat en etnische verschillen slechts één aspect vormen van een 'superdiverse samenleving', zou op uiteenlopende terreinen tot nieuwe inzichten moeten leiden. Vertovec denkt hierbij in het bijzonder aan nieuwe patronen van ongelijkheid, racisme en segregatie, en de invloed van onderlinge contacten in buurten die gekenmerkt worden door superdiversiteit. De aanwezigheid van mensen uit alle werelddelen met verschillende kenmerken zou ook een impuls kunnen bieden aan theorievorming rondom kosmopolitisme en processen van creolisering. Daarnaast wijst Vertovec op ontwikkelingen rondom transnationalisme, integratie en nieuwe en bestaande migratiepatronen die anders ingevuld worden onder invloed van superdiversiteit (Vertovec, 2007: 1044-1047).

In latere publicaties wijst Vertovec erop dat het begrip superdiversiteit te beperkt of te eenzijdig door academici is opgepakt. Zij zouden het vooral gebruiken in de zin van een toenemende diversiteit in culturen of etnische groepen in plaats van te erkennen dat het om multidimensionale veranderingen in migratiepatronen gaat, waarbij er sprake is van diversiteit in migratiepatronen, verblijfsstatussen, gender, leeftijd en het human capital van migranten (zie bijvoorbeeld Meissner \& Vertovec, 2015: 541). Enkele van de hierboven beschreven thema's die met een focus op superdiversiteit andere en nieuwe beelden en kennis opleveren, staan ook centraal in deze inleiding en bij de auteurs in dit themanummer. 
Wat nu 'superdiversiteit' heet, is in feite altijd een kenmerk van groeisteden en metropolen geweest. Chicago fungeert nog steeds als voorbeeld van een migrantenstad die in de periode tussen 1850 en 1920 van een kleine handelspost veranderde in een stad met drie miljoen inwoners. Klassiek is nog altijd de concentrische-zonetheorie van Ernest Burgess (Park \& Burgess, 1925) waarin de 'zone of transition' de meeste nieuwkomers herbergde. De zone bestond uit slums die geteisterd werden door een veelheid van sociale problemen, verloedering en misdaad.

Ook de huidige grote steden in Europa nemen de contouren aan van superdiversiteit: in veel stadsdelen is de oorspronkelijke bevolking slechts één van de vele minderheden geworden. Veel migranten zijn in deze steden neergestreken op zoek naar werk en een beter bestaan. Latere generaties migranten zochten - al dan niet in het kader van gezinshereniging - aansluiting in etnische enclaves binnen de wijken van aankomst. Andere migranten verblijven onrechtmatig in het land en zoeken hun heil onder familieleden en landgenoten en zijn aangewezen op de zwarte arbeidsmarkt met slecht betaalde ' 3 -D (dirty, dangerous, difficult) banen' en verstoken van enige sociale zekerheid (Cremers, 2016; Vogel, 2016). Veel migranten houden het hoofd boven water in lokale netwerken en onderhouden via internet en sociale media contact met mensen in het land van herkomst. Dat geldt voor veel migranten met een niet-westerse achtergrond, maar ook voor bijvoorbeeld Polen en Roemenen die zich in vergelijking met asielzoekers uit Syrië, Afghanistan, Albanië of Eritrea veelal met andere aspiraties en motieven in deze stadsdelen vestigen (zie bijvoorbeeld Weltevreden et al., 2009). De Vlaamse socioloog Dirk Geldof spreekt in dit themanummer over superdiversiteit als een 'onverwerkte realiteit'. De superdiverse conditie in de grote steden bestaat enerzijds uit achterstelling, taalproblemen, isolement, onzekerheid, gevoelens van onrecht en wellicht ook radicalisme en criminaliteit. En aan de andere kant vertaalt deze superdiversiteit zich in uitsluiting, discriminatie, angst en wantrouwen tegenover de komst en de aanwezigheid van nieuwkomers, in het bijzonder met een moslimachtergrond. In die context wordt superdiversiteit als bedreigend ervaren en de autochtone bevolking valt snel terug op de verklaring van 'culturele schuld'. Ook het Sociaal \& Cultureel Planbureau (SCP) signaleert een dergelijke tegenstelling in de Nederlandse samenleving. In Kwesties voor het kiezen analyseren onderzoekers van het SCP enkele wezenlijke maatschappelijke kwesties voor de Tweede Kamerverkiezingen in 2017, waaronder de integratie van migranten. Het SCP constateert dat de niet-westerse migranten en de autochtone Nederlanders elkaar vinden in een gedeeld onbehaaglijk gevoel over de Nederlandse samenleving. Het onbehagen bij de migranten komt echter vooral voort uit gevoelens van uitsluiting en discriminatie. De autochtone Nederlanders voelen zich 'cultureel' bedreigd, waarbij zij zich vooral richten op de binnenkomst van moslims die zij associëren met geweld en waarden die in hun ogen onverenigbaar zijn met Nederlandse waarden. De zogenoemde 'boze witte mannen' herkennen zich niet meer in Nederland en wijzen daarbij bijvoorbeeld op de Zwarte Pieten-discussie (SCP, 2017: 19-22; Van Swaaningen, 2017). 
voor het gevoel niet gehoord te worden, de verstoring van gemeenschap, ondermijning van de nationale identiteit en het verloren gevoel van thuishoren. Cultuur wordt meer en meer als etnisch eigendom geclaimd. Niet verwonderlijk dat plannen voor stedelijke vernieuwing en economische vitaliteit in diverse stadsdelen maar halfhartig worden ondersteund. Eerst zouden de restanten van de multiculturele samenleving moeten worden gesloopt en zouden migranten in de pas moeten gaan lopen van integratieprogramma's. Het debat hierover raakt bij elk incident in staat van verontwaardiging en paniek. Erop wijzen dat superdiverse stadsdelen hun eigen dynamieken hebben en bescherming kunnen bieden aan migranten, werkt als een rode lap op een stier. Zo windt bestuursjurist Jasper Endeman (2017) zich op over het EUgefinancierde onderzoek van Maurice Crul dat 'de geesten rijp moet maken dat autochtone stedelingen slechts één van de vele groepen zijn en zich evengoed moeten aanpassen aan minderheden. Absurder kan het niet worden in het integratiedebat'. De Nederlandse cultuur moet volgens Endeman leidend blijven. 'Al is een "witte” Nederlander nog maar de enige in de wijk, zij moet nog net zo goed een rokje kunnen dragen als dertig jaar geleden. Want dat zij dat kan, is dé norm.'

\section{Etnische concentratie}

De negatieve effecten van etnische segregatie en etnische concentratie zijn al vroeg binnen de criminologische en sociologische wetenschap beschreven. De pioniers van de Chicago School, waaronder Park, wezen erop dat segregatie morele afstand met zich meebrengt, waardoor de stad uiteenvalt in 'een mozaïek van kleine werelden die elkaar wel raken maar niet doordringen' (geciteerd in Chimienti \& Van Liempt, 2015: 21). Vanuit dat perspectief is segregatie een hindernis voor sociale en economische mobiliteit en leidt tot een sociale reproductie van ongelijkheden, tot uitdrukking komend in onder andere armoede, werkloosheid en hoge misdaadcijfers.

Illustratief is een studie van Fenne Pinkster over Transvaal Noord (2007). De sociale contacten in die buurt blijven beperkt tot sterke etnische clusters en andere hechte groepsverbanden met een sterke sociale controle. Het sociale leven op straat is anoniem en rondhangende jongeren en drugsverslaafden roepen onveiligheidsgevoelens op. De hechte netwerken bieden wel onderlinge steun en uitwisseling, maar de gedragscodes belemmeren de jongeren om naar buiten te treden en mogelijkheden in het onderwijs en op de arbeidsmarkt te verkennen. De blik van velen is gericht op werk in de informele economie of gesubsidieerde functies in de buurt zonder veel perspectief op doorstroming. Pinkster wijst ook op deze negatieve socialisering en het ontbreken van goede rolmodellen voor kinderen. Mensen blijven graag wonen in 'hun buurt', waar zij de gedragscodes herkennen en zich op hun gemak voelen.

Nederlands onderzoek naar etnische concentratie laat zien dat migranten in de betreffende wijken zich weinig op Nederland oriënteren; hun taalbeheersing en emancipatorische opvattingen blijven achter. Enkele onderzoekers wijzen erop dat wijken met etnische concentratie een 
waardoor zij in een isolement geraken en de taal onvoldoende leren beheersen (Gijsberts, 2005; Van der Laan Bouma-Doff, 2005; Huijink \& Dagevos, 2016).

Er is ook een ander perspectief op etnische enclaves in superdiverse wijken mogelijk. In een onderzoek naar etnisch clusteren van Somaliërs in Engeland stelden Milena Chimienti en Ilse van Liempt (2015) vast dat Somalische enclaves zowel nieuwkomers opvangen en uitzicht bieden als een barrière kunnen vormen voor sociale mobiliteit. Volgens de auteurs is etnische concentratie een statische en povere term die geen goed zicht biedt op de complexe en uiteenlopende ervaringen van migranten die in etnische enclaves terecht zijn gekomen. Zo vinden veel recente migranten werk in bedrijven in hun eigen etnische gemeenschap. Er bestaat binnen die enclaves onderlinge solidariteit: hulp bij het vinden van werk of een bedrijfje beginnen. Ook asielzoekers neigen ertoe zich te vestigen in de nabijheid van hun voormalige landgenoten. Ze krijgen de nodige hulp en steun in de moeilijke beginperiode nadat ze zijn aangekomen. Etnische enclaves kunnen dus fungeren als 'gateway' voor economische opwaartse mobiliteit. Ze kunnen ook een protectieve functie vervullen. Maar voor anderen vormt de etnische enclave een belemmering. Zij zoeken elders in de stad mensen met eenzelfde leefstijl of een leefstijl die zij ambiëren (Chimienti \& Van Liempt, 2015: 21-23). De opvatting dat etnische segregatie fnuikend is voor integratie en sociale bindingen is bekrachtigd door de socioloog Robert Putnam in zijn invloedrijke artikel 'E Pluribus Unum' (2007). ${ }^{1}$ Volgens Putnam hebben immigratie en etnische diversiteit - althans op korte termijn - een negatief effect op sociale solidariteit en sociaal kapitaal. In de Verenigde Staten neigen bewoners van etnisch diverse wijken ertoe zich terug te trekken ('hunker down'); ze gaan 'overwinteren' in de wijk; het onderlinge vertrouwen kalft daardoor af en coöperatie vermindert. Mérove Gijsberts en collega's hebben Putnam's constrict-hypothese in Nederland getoetst en concludeerden dat slechts één aspect van etnische diversiteit, namelijk de mate van lokale contacten, een negatief effect sorteerde. Vooral blanken blijken minder interetnische contacten aan te gaan (Gijsberts et al., 2012).

Beleidsmakers blijven doorgaans trouw aan het dominante discours waarin etnische concentratie enerzijds tot gettovorming zou leiden en anderzijds een barrière voor integratie vormt en illustratief is voor minderheden die er niet in slagen sociaal en cultureel te integreren. Etnische groepen zouden zich beperken tot 'parallel lives' die contacten en bindingen met de bredere samenleving hinderen. Zo sprak voormalig minister Asscher van Sociale Zaken en Werkgelegenheid de afgelopen jaren herhaaldelijk zijn zorg uit over de groei van 'parallelle gemeenschappen' in de Nederlandse samenleving, verwijzend naar onder andere Turks-islamitische groeperingen die met de rug naar de Nederlandse samenleving zouden staan (zie Sunier \& Landman, 2014; Huijink \& Dagevos, 2015: 30-31). ${ }^{2}$ Het betreft hier migranten die op grote afstand van 'mainstream Nederland' zijn komen te staan voor wat betreft hun sociale contacten, waardeoriëntaties en hun identificatie met de herkomstgroep en met autochtone Nederlanders (Dagevos \& Huijnk, 2015: 7). 
negatieve buurteffecten geplaatst. Zo zetten Jolijn Broekhuizen en Ron van Wonderen (2012) uiteen dat naarmate de etnische diversiteit in een buurt groter is, er significant vaker sprake is van spanningen. De diversiteit van bevolkingsgroepen vergroot de kans op verschillende leefwijzen en daarmee op botsende omgangsvormen en normen en waarden. Op de vraag hoe dat precies in het publieke domein tot uitdrukking zou komen, gaan de auteurs overigens niet in. Ook de term 'etnisch scheidingsveld' sluit aan op de wijdverbreide opvatting dat etnische concentratie wel negatieve effecten moet sorteren. Talja Blokland (2005) betoogde in haar proefschrift over Hillesluis dat incidenten zoals strijd over het gebruik van een plein vaak worden geïnterpreteerd langs etnische lijnen. Zo voelen witte Nederlanders zich bedreigd in hun eigenaarschap van de publieke ruimte wanneer Marokkaanse jongens zich die toeëigenen. Het symbolisch eigendom van ruimte wordt uitgedaagd.

\section{Blanke zelfsegregatie}

Het dominante politieke vertoog luidt dat etnische segregatie een hindernis vormt voor individuele migranten om sociaal te stijgen en de sociale cohesie bedreigt, omdat minderheidsgroepen afstand bewaren. Dat etnisch clusteren solidariteit kan bevorderen, bedrijvigheid kan stimuleren en een beschermende functie heeft tegen discriminatie en racisme, speelt in dat vertoog geen enkele rol. Mede in reactie op problemen en kwalen van etnische concentratie is het beleid sterk gaan inzetten op 'sociaal mengen'. Het beleid beoogt dan ook tot 'evenwichtige samenstelling' van buurten te komen en de buurten aantrekkelijk te maken voor huishoudens met hogere inkomens en hogere opleiding. Een variant daarvan is het benutten van de 'creatieve klasse' (Florida, 2002). Deze creatieve mensen zouden wonen in een diverse omgeving op prijs stellen en hun komst zou voordelen brengen, onder andere in termen van contacten en verbreding van sociale netwerken. Niettemin, het meeste onderzoek wijst uit dat sociaal mengen weinig resultaten geeft. ${ }^{\mathbf{3}}$ Het aantrekken van koopkrachtige bewoners in etnisch diverse wijken draagt niet bij aan sociale cohesie en integratie.

Zoals gezegd, de meeste beleidsinterventies worden genomen in een sterk gepolitiseerde context, waarin etnische segregatie (vooral van zwarte bevolkingsgroepen en de moslimbevolking) onder verdenking staat. Opvallend is dat tendensen van zelfsegregatie onder de blanke bevolking, zoals het afgezonderd gaan wonen in suburbs en gated communities, nauwelijks wordt geproblematiseerd (Phillips, 2010). Ook minderheden die cultureel gesegregeerd zijn, maar economisch geïntegreerd - waaronder de Chinese bevolkingsgroep en de orthodoxe Joodse gemeenschap in Antwerpen - worden niet geproblematiseerd. Zij worden kennelijk niet als bedreigend gezien.

Fenne Pinkster deed onderzoek naar vooral blanke middenklasse huishoudens in sommige Haagse en Amsterdamse achterstandswijken en stelde vast dat zij geen voorliefde voor etnische diversiteit hebben en geen vormen van solidariteit met andere bewoners koesteren. Eerder is sprake van een 'strategie van non-belonging': op voorhand geen 
uit dat gebrek aan binding deze burgers beschermt tegen buurtwanorde

(Pinkster, Permentier \& Wittebrood, 2014).

Veel autochtone burgers die naar de suburbs en geprivatiseerde enclaves zijn vertrokken, geven aan dat zij zich niet meer thuis voelden in hun voormalige woonbuurt in de stad (zie o.a. Reijndorp, 2004). Daarbij speelt mee dat velen een gevoel van machteloosheid ervaren om controle uit te oefenen in publieke ruimtes die etnisch divers zijn geworden. Ze beseffen dat zij de eigen waarden in de betreffende ruimte niet zomaar kunnen opleggen (Bannister \& Kearns, 2013: 2705/8). In die context is het ervaren van verschil een bedreiging: anderen verstoren de gemoedsrust en geprefereerde levenswijzen. Mede daarom, zegt socioloog Richard Sennett (1996), ontstaat een aandrang om dat verschil te neutraliseren en te domesticeren. Maar daarmee gaat het vermogen om te onderhandelen over het gezamenlijk gebruik van de publieke ruimte teloor.

Interessant in dit verband is wat de etnograaf Gerald Suttles (1972) aanduidde als defended neighborhoods: aparte gebieden binnen de buurt die bescherming bieden tegen de wanorde, onzekerheid en onveiligheid van het stadsleven. De grenzen van een defended neighborhood kunnen inkrimpen tot enkele straten of een appartementencomplex. Een opeenstapeling van leefbaarheidsproblemen kan ertoe leiden dat de waargenomen reikwijdte van de buurt inkrimpt of zelfs dat de wijdere buurt als geheel wordt weg gedefinieerd. Buurtverdediging kan volgens Suttles bestaan uit een variëteit van handelingen, van gebruik van private beveiligers, tot vigilantisme en straatbendes.

Terwijl Park en zijn collega's buurten zagen als etnisch homogene eenheden die zich tegen invasie van etnische anderen verzetten, wijst Suttles erop dat defended neighbourhoods doorgaans heterogeen zijn samengesteld. Hij spreekt over pan-etnische solidariteiten om aan te tonen dat de defensieve mentaliteit niet gelieerd is aan etnische identificaties. Anderen benutten de hypothese van defended neighbourhood om discriminatie en racisme van meerderheidsgroepen te verklaren die geconfronteerd worden met de instroom van minderheden in hun wijk. Volgens sommige onderzoekers vertonen die buurten de hoogste cijfers van haatgerelateerde misdaad. De witte homogeniteit staat onder druk: de vreemdeling is immers - zoals Georg Simmel opmerkte - 'no owner of the soil' (Grattet, 2009: 147).

\section{Superdiverse wijken, conviviale omgangsvormen en conflicten}

Sinds een jaar of vijftien komen andersoortige bevindingen naar voren. Het gaat dan niet om de zoveelste toets in hoeverre etnische segregatie een hindernis is voor integratie en burgerschap, maar om etnografische studies naar het dagelijks leven van migranten in superdiverse wijken. Die onderzoeken geven meer inzicht in zowel de vaak besloten werelden van etnische clusters als de omgangsvormen in het publieke domein in etnisch gesegregeerde buurten. Wat dat laatste betreft: veel onderzoekers wijzen op een ontspannen omgang met verschillen in superdiverse buurten. Sommigen spreken in dat verband over convivialiteit, anderen 
superdiverse wijken zou zijn ontstaan. Dat begrip duidt dan op het gezamenlijk benutten van straat, plein en winkels in elkaars nabijheid. Met name socioloog Paul Gilroy (2004) heeft geijverd voor een herleving van het begrip - dat door Ivan Illich werd gemunt - onder meer omdat vaste categorieën van etniciteit er in een conviviale cultuur niet toe doen. Etnische verschillen worden niet geacht het gezamenlijk betreden van publieke ruimtes te verstoren of angst te genereren. Intussen lijkt dat begrip aan een opmars bezig en er zijn verschillende themanummers in internationale tijdschriften aan gewijd. ${ }^{4}$ Sommigen vatten convivialiteit op als wederzijdse respectvolle relaties ten aanzien van buren in wijken of stadsdelen (Nowicka \& Vertovec, 2014: 345). Het concept biedt ook ruimte voor openheid en de accommodatie van verschillen en empathie voor vreemden. Zo stelde Jan Blommaert vast dat in het Antwerpse OudBerchem sprake is van een mate van sociale cohesie die in scherp contrast staat tot het publieke beeld van verval en degradatie van het gebied (Blommaert, 2014: 448).

Susanne Wessendorf (2013; 2016) spreekt in haar onderzoek in Hackney (London) over het ontstaan van een 'commonplace diversity'. Die term wijst op een culturele diversiteit die ervaren wordt als een normaal deel van het sociale leven. De bewoners hebben een gevoel van thuishoren ontwikkeld, vooral op basis van het besef dat zij op straat niet anders of afwijkend zijn. Daarnaast is een stilzwijgend 'ethos of mixing' gegroeid dat volgens Wessendorf tot uitdrukking komt in kritiek op groepen die op straat niet wensen te mengen, waaronder hipsters en andere jonge trendy mensen, en heel anders: orthodoxe Joden. Er ontstaan spanningen, bijvoorbeeld wanneer panden door hipsters of leden van de Joodse gemeenschap worden opgekocht. Er doen zich ook spanningen voor tussen langer verblijvende bewoners (zowel Britten als etnische minderheden) en nieuwkomers en vooral asielzoekers en illegaal verblijvende personen.

De mogelijkheid om onopgemerkt door straten te gaan wordt door bewoners gewaardeerd, vooral door vrouwen die een hoofddoekje dragen. Dit leidt volgens Wessendorf tot een gevoel sociaal geaccepteerd te worden (2016: 455). Ook al hebben ze moeilijkheden met een wettelijke status, toegang tot werk of woning, deze migranten voelen zich thuis in dit stadsdeel, omdat verschil wordt geaccepteerd in de publieke en semipublieke ruimte. Zij hebben overigens onverminderd te maken met racisme, seksisme of andere vormen van discriminatie. Zo bestaat er volgens Wessendorf een geïnstitutionaliseerd racisme tegen zwarte jeugd en zijn er grote barrières voor hoger opgeleide recente migranten om werk te vinden (2016: 460).

Wessendorf en andere onderzoekers wijzen op processen van normalisering op wijkniveau: in dagelijkse interacties lijken etnische verschillen naar de achtergrond te verdwijnen. Maar die normalisering zo merkt Geldof in dit nummer op - 'is geen rechtlijnig proces, maar één met vallen en opstaan. De gewenning aan diversiteit en verschil in dagelijkse interacties betekent dus zeker niet dat contacten conflictvrij zijn'. Ico Maly zet in dit nummer uiteen dat nieuwkomers met geld en een hippe leefstijl het beeld van de multiculturele Gentse wijk Rabot ingrijpend hebben veranderd. Die hipsterificatie wordt door de lokale 
kunnen dus gepaard gaan met discriminatie, conflicten over ruimtegebruik en het aanscherpen van grenzen (zie ook Nowicka \& Vertovec, 2014).

Simon Pemberton en Jenny Phillimore (2016) zijn in hun onderzoek in twee Britse superdiverse wijken op de volgende spanningen en conflicten gestuit. Het demonstratief onder de aandacht brengen van de 'eigen' nationale identiteit van hun land van herkomst roept soms irritatie op bij andere groepen. Ook kunnen zich spanningen voordoen tussen gevestigde migranten en net aangekomen migranten binnen een en dezelfde etnische bevolkingsgroep. Zo voelen jonge Polen zich vervreemd van oudere generaties die trouw zijn aan de katholieke kerk; zij richten zich minder op de buurten van die generaties. Anderen daarentegen, zoals Somaliërs, stellen de diverse publieke ruimte op prijs, omdat het behoedt voor racisme. Zij kunnen zich juist minder goed identificeren met minder diverse wijken, waar ze meer zouden opvallen en met racisme worden geconfronteerd (ibid., 2016: 14).

Naast mogelijke spanningen en conflicten tussen groepen in multietnische stedelijke gebieden wijst Vertovec ook op de toegenomen diversiteit binnen groepen. Enkele kwalitatieve studies over jongeren met een Turkse of Koerdische achtergrond kunnen dat duidelijk maken (Staring et al., 2014; Geelhoed \& Staring, 2015). Waar sommige Nederlands-Turkse jongeren zich primair identificeren als moslim, identificeren andere jongeren zich met Rotterdam, Nederland, Koerdistan, Turkije of een combinatie hiervan. Deze jongeren verschillen ook sterk van elkaar in hun sociale contacten. Waar sommigen vooral met andere Turks-Nederlandse jongeren omgaan, zijn er ook jongeren die een etnisch heterogene vriendengroep hebben en anderen die weer primair contacten met autochtone Nederlanders onderhouden. Voor vrijwel alle jongeren is de islam in meer of mindere mate van belang, maar tegelijkertijd maken jongeren deel uit van verschillende islamitische organisaties en stromingen als de Milli Görüş, Diyanet, Hizmet (de beweging van Fethullah Gülen), Hizb ut Tahrir, Alevi, enzovoort. Het zijn grotendeels dezelfde verschillen tussen deze jongeren die ten grondslag liggen aan de onderlinge spanningen tussen migranten met een Turkse achtergrond en in relatie tot Turkije. Met de landelijke Nederlandse politiek hebben deze jongeren niet zo veel, lokaal en transnationaal zijn ze echter wel degelijk politiek betrokken. Deze transnationale betrokkenheid is de afgelopen jaren en in het bijzonder in de nasleep van de coup in Turkije in de zomer van 2016 via de onderlinge spanningen en conflicten ook in Nederland zichtbaar geworden (Staring et al., 2014; Geelhoed \& Staring, 2015).

\section{Kritiek}

Genoemde analyses van superdiverse wijken lokken herhaaldelijk kritiek uit. Zo keert Jan Willem Duyvendak zich in dit nummer tegen de veronderstelling dat deze wijken over een common-place diversiteit zouden beschikken. 'Ook wanneer individuen met een native meerderheidsachtergrond zich in deze omgeving bevinden zullen zij hun gedrag aanpassen zodat het past bij de superdiverse omgeving.' Volgens 
overal op en ook lang niet in alle superdiverse contexten. Zo leert onderzoek van Paul Mepschen (2016) in Amsterdam Nieuw-West dat er juist sprake is van een toename van als problematisch ervaren verschillen. Dat is strijdig met de hypothese van 'welwillende superdiversiteit'. Vooral blanke bewoners ervaren de 'gemengde' publieke ruimte als bedreigend. Ze vinden de buurt niet meer Nederlands. De auteur constateert een autochtone politisering van verschil langs de lijnen van cultuurverlies en cultureel protectionisme. De vraag is uiteraard of Amsterdam Nieuw-West wel te vergelijken is met Hackney. In die laatste wijk lijken etnische verschillen wel degelijk naar de achtergrond te zijn gedrongen.

Daarnaast hebben sommige auteurs 'convivialiteit' bekritiseerd als een 'happy multiculturalism' (zie Back \& Sinha, 2016). De vraag is of er niet een teveel aan 'gezamenlijkheid' en 'onderling respect' (of respect voor verschil) in het begrip wordt gelegd. Bovendien lijkt het begrip meer geëigend voor de ontspannen omgangsvormen in centrum- en uitgaansgebieden, binnen de zogenoemde 'third spaces' (Oldenburg, 1989). Het is de vraag of migranten die dagelijks bezig zijn met de vraag hoe zij het hoofd boven water kunnen houden wel altijd toekomen aan dergelijke omgangsvormen.

Wellicht kan het begrip wel gereserveerd worden voor alledaagse, tijdelijke en tamelijk triviale interacties in de publiek ruimte, bijvoorbeeld alledaagse gesprekken in winkels. Je kunt dan spreken over 'civic ease' (Wessendorf, 2016) of 'comfort zones' (Blokland \& Nast, 2014). In een comfort zone zijn geen inspanningen nodig om contacten te maken; de omgeving voelt vertrouwd aan. Het gaat daarbij niet om een ethos of om sterkere sociale binding. Begrippen als 'commonplace diversity' en 'ethos of mixing' suggereren dat bewoners diversiteit als de norm zouden beschouwen. De conclusies van Pemberton en Phillimore liggen echter meer voor de hand. Superdiverse wijken vormen geen conviviale 'third spaces' waar de norm van diversiteit geldt, maar 'liminal spaces' waar geen dominante identiteit verankerd kan raken. Andere critici zoals de sociologen Les Back en Shamser Sinha (2016) menen dat superdiversiteit een politiek eendimensionaal concept is dat de scheidslijnen en (machts)ongelijkheden binnen de stedelijke multietnische buurten miskent. Bovendien gaat het om buurten waarin sprake is van surveillance, politieel toezicht en geïnstitutionaliseerde marginalisering. Weliswaar is Vertovec zich bewust van conflicten (Nowicka \&Vertovec, 2014), maar hij zou te veel geloof hechten aan de positieve kenmerken van samen doen en leven in contexten van diversiteit. Niettemin beamen Back en Sinha dat superdiverse contexten emancipatoire mogelijkheden bieden die nog niet onderkend worden. Die zouden niet in termen van een buurtidentiteit of een culturele ecologie gegoten moeten worden, maar van individuele capaciteiten en tools die benut kunnen worden om vooruit te kunnen komen. Daartoe behoren nieuwsgierigheid, belangstellend zijn en verleggen van perspectief. Het gaat om een set van 'navigation devices', waardoor jonge migranten de weg vinden te midden van de vele hindernissen (Back \& Sinha, 2016: 530).

Andere critici betogen dat het integratiebeleid (of breder: mainstream- 
en aansluiting te zoeken bij (hoger) onderwijs en de arbeidsmarkt.

Daarbij speelt dat bij veel immigranten het perspectief op vooruitgang de afgelopen decennia pregnant verschoven is: zij erkennen dat de toekomst in het nieuwe thuisland ligt.

Anderzijds doen zich in superdiverse wijken processen van marginalisering, discriminatie en exclusie voor. Het gaat hier enerzijds om processen van uitsluiting van migrantengroeperingen ten opzichte van de dominante samenleving en tegelijkertijd ook vormen van uitsluiting binnen deze migrantengroeperingen. Zo laten twee recente studies onder in Nederland geboren en getogen jongeren met een Turkse en met een Marokkaanse achtergrond zien hoe sterk zij zich uitgesloten voelen door de dominante Nederlandse samenleving. Deze jongeren hebben het gevoel dat er met twee maten wordt gemeten en dat zij 'nooit Nederlander genoeg' zullen zijn (Stercxk \& Van der Ent, 2015; Geelhoed \& Staring, 2015). Tegelijkertijd spelen er allerlei spanningen en vormen van uitsluiting binnen de Turks-Nederlandse migrantengroep (Geelhoed \& Staring, 2015). Deze diversiteit onder de Turkse Nederlanders en hun transnationale bindingen vormt voor de Nederlandse overheid enigszins eufemistisch gesteld een uitdaging. Niet alleen is onduidelijk waar en hoe de onderlinge spanningen liggen, ook is het vaak onduidelijk wie wie kan vertegenwoordigen.

Dergelijke conflicten en spanningen vallen bovendien samen met gevoelens van onveiligheid onder burgers, die sterk gekoppeld worden aan de islam en de komst van moslims (SCP, 2017) en gevoed worden door terroristische aanslagen in naam van de islam in verschillende Europese steden. Multi-etnische wijken zouden een broedplaats van jihadisme zijn. Na de aanslagen in Brussel en op luchthaven Zaventem in maart 2016 is dan ook veel studie gemaakt van de gemeente Molenbeek en het geïntensiveerde Brusselse politie- en veiligheidsbeleid (Devroe \& Ponsaers, 2016; Leman, 2017). Maréchal en anderen (2014) schrijven ook over een spiraal van wederzijdse afzondering tussen moslims en niet-moslims in Brussel. Tegelijkertijd bestaat er een groeiende afstand tussen verschillende moslimgroeperingen. Waar alle moslims worden aangesproken op de gewelddadige strijd die ISIS in Syrië en in de verschillende Europese steden voert, herkennen veruit de meeste moslims zich niet in de gewelddadige islam van ISIS noch koesteren zij enige sympathie voor de terroristen die in naam van de islam in Europese steden aanslagen plegen (Geelhoed \& Staring, 2015; Stercxk \& Van der Ent, 2015).

\section{Herziening van vooronderstellingen?}

Het concept 'superdiversiteit' is allerminst onomstreden, maar het is evident dat het ook als een inspirerend analytisch concept fungeert. Een concept dat vele academici aanspoort tot onderzoek en verder nadenken over de aard, omvang, waarde en mogelijke implicaties van 'superdiversiteit'. De kracht van het concept superdiversiteit ligt ook in de beschrijving die expliciet ruimte creëert voor een multifocale bril met oog voor sociaaleconomische, religieuze, transnationale en politieke verschillen naast uiteenlopende sociale contacten en verblijfsstatussen in 
De opbrengst van studies naar superdiversiteit is ook dat zij de consensus over etnische concentratie en defensieve mentaliteiten doorbreken. Onderzoek naar superdiversiteit relativeert en slaat bressen in Putnams constrict hypothese en andere mainstream theorieën over de kwalen van etnische segregatie. In wijken van aankomst zijn bewoners niet steevast tot angst en machteloosheid gedoemd. Superdiverse buurten waarin grote (blanke) minderheidsgroepen ontbreken, zijn juist vaak veiliger en bieden doorgaans meer bescherming tegen discriminatie en racisme. In sommige superdiverse wijken is het gemakkelijker over etnische, raciale en religieuze verschillen heen te kijken. De kans op netwerkvorming voor migranten lijkt daar groter dan in wittere wijken (bijvoorbeeld aanknopen van gesprekken op school over etnische grenzen heen).

Een aantal vooronderstellingen in onderzoek naar etnische concentratie lijken niet goed doordacht. In dergelijke stadsgebieden zou negatieve beeldvorming over en weer niet snel doorbroken kunnen worden, waardoor sociale spanningen kunnen oplopen. Dat is maar de vraag (zie bijvoorbeeld Blommaert, 2014). Ook is het de vraag of culturele afstand - relatief weinig contacten en emotionele binding met de mainstream samenleving - per definitie betekent dat niet aan de eisen van sociaaleconomische participatie kan worden voldaan (Van den Brink, 2006). Evenmin heeft aanhoudende immigratie van oude stadswijken per se een 'culturele hogedrukpan' gemaakt. Ook het beeld dat etnisch diverse wijken per definitie veel misdaad met zich meebrengen, behoeft bijstelling. In Berchem constateerde Blommaert dat gewelddadige misdaad weinig voorkomt en als zich incidenten voordoen, dat die leiden tot 'grote interetnische solidariteit'. Die bevinding staat op gespannen voet met het mainstream discours dat buurten met veel etnische diversiteit in hoge mate instabiel zijn en geteisterd worden door conflicten (zie ook Nowicka \& Vertovec, 2014: 449).

Op basis van bevindingen over superdiverse wijken ontstaat ook beter zicht op de uiteenlopende belangen en behoeften van groepen die met achterstanden kampen. Daardoor komen de tekorten van het gangbare burgerschaps- en integratiebeleid beter aan het licht: integratie zou zich enkel kunnen voltrekken binnen het keurslijf van individuele verantwoordelijkheid, terwijl dat individuele parcours middels omstreden maatregelen wordt afgedwongen (in Nederland o.a. via leningen en boetes in het kader van de inburgering). Het gangbare integratiebeleid wil en kan slechts faciliteren in termen van 'keuzes' en 'individuele mogelijkheden' (Nowicka \& Vertovec, 2014).

Het is ook de vraag of de geijkte reactiepatronen van politie en justitie wel goed zijn doordacht. In etnisch gesegregeerde wijken die hoog op de onveiligheidsmatrix scoren, zouden een zero tolerance-aanpak en een 'lik op stuk'-beleid vereist zijn om verder afglijden te voorkomen. De kans is groot dat die maatregelen juist weerstand en verzet oproepen, terwijl het imago van de politie onder de lokale bevolking verdere deuken oploopt. Opnieuw: de ene superdiverse wijk is de andere niet. De ene gaat gebukt onder drugshandel en agressie van jeugdige bendes, de andere zoals De Pijp in Amsterdam of Oud-Berchem in Antwerpen hebben veel minder te maken met zichtbare vormen van overlast en 
onder meer verwoord in het rapport Werelden van verschil (Huijnk et al., 2015) niet van de baan. In dat rapport stellen de auteurs - net als eerdere SCP-rapporten - vast dat de interetnische verhoudingen onder druk staan. Het stereotiepe denken over en weer is groot en de verschillen in opvatting lijken nauwelijks overbrugbaar. 'Aan de ene kant staan moslims die van mening zijn dat zij en hun religieuze groep als tweederangsburgers worden beschouwd, en aan de andere kant staan autochtone Nederlanders die de aanwezigheid van moslims en migranten als bedreiging van belangrijke waarden zien en hen met criminaliteit en geweld associëren' (Huijnk et al., 2015: 28). De vraag is echter wat de antwoorden op survey-stellingen als 'Ik voel mij helemaal niet Nederlander' uiteindelijk zeggen over de sociaal-culturele afstand tussen scholieren uit uiteenlopende etnische herkomstgroepen tot de Nederlandse samenleving. Bekend is dat enquêteonderzoek naar emotioneel beladen kwesties zoals punitiviteit stereotiepe antwoorden naar boven haalt, zeker wanneer algemene stellingen worden voorgelegd. Veel van de hierboven besproken kwalitatieve onderzoeken naar intercultureel samenleven in multi-etnische wijken brengen een grotere variatie en rijkdom aan opvattingen onder de aandacht. Die onderzoeken schetsen een ander en wellicht reëler beeld van de moeilijkheden waarmee migranten in die wijken worstelen, hun onbegrip en wantrouwen, maar ook de kansen en mogelijkheden om vooruit te komen.

\section{De bijdragen in dit nummer}

De auteurs die in dit themanummer aan het woord komen, is gevraagd in te gaan op de spanningen en conflicten die mogelijk kunnen voortspruiten uit de 'superdiverse conditie'. Hoe verloopt de interactie tussen migranten en de autochtone bevolking in superdiverse wijken? In welke opzichten hebben migranten te maken discriminatie en uitsluiting en wordt wantrouwen geuit jegens de politie en andere overheidsinstellingen?

In het inleidende artikel geeft Dirk Geldof aan dat meer en meer WestEuropese steden majority-minority-cities zijn geworden. Hij gaat in op drie dimensies van dat begrip: de stedelijke context van groeiende diversiteit, de aard en samenstelling van diversiteit en het proces van normalisering (de gewenning aan diversiteit en verschil in dagelijkse interacties). Vervolgens richt Geldof zich op de regularisatie van mensen zonder papieren in Antwerpen in 2009 en de aanwezigheid van transmigranten in Antwerpen en Brussel in 2015. De auteur betoogt dat een focus op die informele stad noodzakelijk is om superdiversiteit te begrijpen. Hij beklemtoont dat het omgaan met de informele stad een 'moeilijke evenwichtsoefening' is voor bestuurders die moeilijk voorbij kunnen lopen aan de aanwezigheid van deze verborgen groepen. De erkenning van het bestaan van die groepen vindt zelden openlijk plaats. Maurice Crul en Frans Lelie concentreren zich op mensen van Nederlandse afkomst in superdiverse meerderheid-minderheden wijken in Amsterdam en Rotterdam waar de meerderheid van de bevolking een migratieachtergrond heeft. Op basis van een survey gaan de auteurs na 
Wordt in Amsterdam diversiteit in sterkere mate als een verrijking ervaren? De auteurs geven een bevestigend antwoord. In Amsterdam zijn veel meer mensen werkzaam in creatieve beroepen en zij neigen ertoe culturele diversiteit in de stad als een verrijking te zien. Mensen in beroepen die juist gericht zijn op handhaving en controle lijken de culturele diversiteit eerder als een bedreiging te zien.

Ico Maly focust op de Gentse wijk Rabot die de laatste decennia een facelift heeft gekregen, onder andere door gentrificatieprojecten. Mede ten gevolge van dit beleid en de aantrekkelijkheid van Gent voor toeristen, is er een 'proces van hipsterificatie' op gang gekomen. De auteur vraagt zich af hoe de gentrificatie in zijn werk is gegaan, welke rol real estate bedrijven daarbij spelen en welke impact die verandering heeft op de samenstelling en stratificatie binnen de wijk. Maly bespreekt het discours van de Gentse beleidsmakers over superdiversiteit en Gent als 'hippe stad' dat ten grondslag ligt aan het stedelijk vernieuwingsbeleid van de stad. Vervolgens illustreert hij met behulp van een etnografisch linguïstisch landschapsonderzoek hoe de Gentse identiteit in Rabot 'verhipstert' is en een transnationaal nicheproduct is geworden. Maly wijst erop dat deze veranderingen problemen voor migrantengroepen creëren en voordelen voor hipsters, ook al zijn ze geen autochtone Gentenaren.

Ten slotte is een artikel opgenomen van Fatima el Bouk, Vita van der Staaij-Los, Tjitske Lovert-Reindersma en Baukje Prins over onrust en spanningen op een superdiverse school. De auteurs gaan onder meer in op de volgende vragen: in hoeverre en hoe zijn spanningen en conflicten in superdiverse mbo-klassen terug te voeren op opvattingen en vooroordelen met betrekking tot etniciteit en religie? Een jaar lang volgden zij de wederwaardigheden op een mbo-instelling gevestigd in de Randstad om te concluderen dat interacties op grond van gedeelde belangen of interesses tussen studenten van diverse etnische en religieuze komaf veel vaker voorkwamen dan vermijdings- of conflictueus gedrag. Veruit de belangrijkste bindingsfactor was de opleiding zelf en 'het behalen van het diploma'. De auteurs stelden overigens wel spanningen en conflicten vast, maar zelden lagen hier etnische of religieuze scheidslijnen aan ten grondslag.

Naast deze artikelen zijn vier discussiebijdragen in het nummer opgenomen. In de 'superdiverse conditie' ontstaat volgens Hans Boutellier een duizelingwekkend perspectief, dat aansluit bij het beeld van een netwerksamenleving zonder eenduidige collectieve gehelen. Een samenleving als een 'caleidoscopisch geheel van identiteiten, relaties, talen en goden in een context van permeabele geografische gebieden'. Dat brengt vele problemen met zich mee, maar het gaat er volgens Boutellier om deze diversiteit productief te maken. Jan Willem Duyvendak betoogt dat pleitbezorgers van superdiversiteit een potentieel blinde vlek hebben voor verschillen in symbolische macht die invloed hebben op integratie. Zij hebben vooral onvoldoende oog voor de mainstream, voor de dominante manieren van denken en doen in een samenleving. Volgens Duyvendak wordt de meerderheidsbevolking van Nederland steeds meer cultureel homogeen, waarbij culturele diversiteit steeds meer als een groeiend probleem wordt 
Ilona van Breugel en Peter Scholten verbinden de discussie over superdiversiteit met de kritiek op klassiek integratiebeleid dat zich op een te simplistische wijze richt op traditionele etnische groepen en daarmee de diversiteit tussen en binnen migrantengroepen negeert. $\mathrm{Zij}$ stellen zich net als Vertovec de vraag op wie dergelijk integratiebeleid in de superdiverse samenleving zich zou moeten richten. De auteurs wijzen op een Europese trend van mainstreaming, waarbij klassiek integratiebeleid wordt vervangen door generiek integratiebeleid dat zich richt op de volledige bevolking. Zij stellen zich hierbij de vraag of deze brede mainstreaming benadering een alternatief kan zijn voor de kritiek vanuit het superdiversiteitsperspectief op het klassieke integratiebeleid. In de vierde en laatste discussiebijdrage richten Erik Snel en Iris Glas zich op de complexe relaties tussen (super)diverse buurten, criminaliteit en onveiligheidsgevoelens. Voortbouwend op het werk van Putnam stellen zij dat een toenemende etnische diversiteit in steden een negatief effect heeft op de criminaliteitscijfers en gevoelens van onveiligheid bij burgers in die steden. De uitkomsten van kwalitatieve studies laten echter juist zien dat bewoners van homogene buurten migranten als bedreigend ervaren en dat bewoners van superdiverse buurten door hun bekendheid met migranten hen juist als minder bedreigend ervaren. Tegelijkertijd kunnen negatieve ervaringen met slachtofferschap, ontevredenheid met de buurt en wantrouwen in de overheid een verklaring bieden voor de conclusie dat deze bewoners zich in hun superdiverse buurt vaker onveiliger voelen.

Tot slot schrijft René van Swaaningen voor de rubriek 'Voorbij de horizon' over Stanley Cohen en zijn criminologische erfenis. Aan de hand van de in 1988 verschenen bloemlezing Against Criminology ('ja') en de recent verschenen bloemlezing Outside Criminology ('nee, dat niet') schetst de auteur een prachtig beeld van Stanley Cohen als origineel en autonoom denker en als vernieuwer van de criminologie.

\section{Literatuur}

Back, L. \& S. Sinha (2016), Multicultural conviviality in the midst of racism's ruins. Journal of Intercultural Studies, 37, 517-32.

Bannister, J. \& A. Kearns (2013), The function and foundations of urban tolerance: Encountering and engaging with difference in the city. Urban Studies, 50(13), 2700-17.

Blokland, T. (2005), Goeie buren houden zich op d'r eigen. Buurt, gemeenschap en sociale relaties in de stad. Den Haag: Dr. Gradus Hendriks Stichting.

Blokland, T. \& G. van Eijk (2010), Do people who like diversity practice diversity in neighborhood life? Neighborhood use and the social networks of 'diversity-seekers' in a mixed neighborhood in the Netherlands. Journal of Ethnic and Migration Studies, 36(2), 313-332. 
International Journal of Urban and Regional Research, 38(4), 11421159.

Blommaert, J. (2011), Superdiversiteit maakt integratiebeleid irrelevant. www.socialevraagstukken.nl/superdiversiteit-maaktintegratiebeleid-irrelevant .

Blommaert, J. (2014), Infrastructures of superdiversity: Conviviality and language in an Antwerp neighbourhood. European Journal of Cultural Studies, 17(4), 431-451.

Brink, G. van den (2006), Culturele contrasten. Het verhaal van de migranten in Rotterdam. Amsterdam: Bert Bakker.

Broekhuizen, J. \& R. van Wonderen (2012), Samenleven met verschillen. Signaleren van spanningen en versterken van vertrouwen in Amsterdamse buurten. Amsterdam: Verwey-Jonker Instituut \& Bureau Onderzoek en Statistiek $(\mathrm{O}+\mathrm{S})$.

Chimienti, M. \& I. van Liempt (2015), Super-diversity and the art of living in ethnically concentrated urban areas. Identities: Global Studies in Culture and Power, 22(1), 19-35.

Cremers, J. (2016), Construction labour, mobility and non-standard employment. The European Trade Union Institute's (ETUI) Health and Safety at Work Magazine, spring-summer 2016, 17-22. www.etui.org/Topics/Health-Safety-workingconditions/HesaMag/Construction-workers-at-the-mercy-of-socialdumping.

Dagevos, J. \& W. Huijink (2015), Samenvatting en slotbeschouwing. In: W. Huijnk, J. Dagevos, M. Gijsberts \& I. Andriessen (red.), Werelden van verschil. Over de sociaal-culturele afstand en positie van migrantengroepen in Nederland. Den Haag: SCP, 7-29.

Devroe, E. \& P. Ponsaers (2016), De wonden en littekens van Molenbeek: Parijs, 13 november 2015 - Brussel, 22 maart 2016, Handboek Politiediensten, Veiligheidsbeleid 119: 1-27.

Duyvendak, J.W., P. Geschiere \& E. Tonkens (eds.) (2016), The Culturalization of Citizenship. Belonging and Polarization in a Globalizing World. London: Palgrave Macmillan UK.

Duyvendak, J.W., L. Veldboer \& C. Bouw (2008), De Mixfactor: integratie en segregatie in Nederland. Amsterdam: Boom.

Endeman, J. (2017), Integratie kan maar een kant op gaan: de heersende norm blijft. Trouw 6 april 2017. www.trouw.nl/opinie/integratie-kanmaar-een-kant-op-gaan-de-heersende-norm-blijft ac48a215 . 
Geelhoed, F. \& R. Staring (2015), 'Nooit Nederlander genoeg' Turks-

Nederlandse jongeren over hun sociaal-culturele posities, wereldbeelden en attitudes ten opzichte van (religieus geïnspireerd) geweld. In: W. Huijnk, J. Dagevos, M. Gijsberts \& I. Andriessen (red.), Werelden van verschil. Over de sociaal-culturele afstand en positie van migrantengroepen in Nederland. Den Haag: SCP, 160-218.

Gijsberts, M., T. van der Meer \& J. Dagevos (2012), 'Hunkering down' in multi-ethnic neighbourhoods? The effects of ethnic diversity on dimensions of social cohesion. European Sociological Review, 28(4), 527-537.

Gijsberts, M. \& J. Dagevos (2005), Uit elkaars buurt. De invloed van etnische concentratie op integratie en beeldvorming. Den Haag: SCP.

Gijsberts, M. \& J. Dagevos (2007), Interventies voor integratie. Het tegengaan van etnische concentratie en bevorderen van interetnisch contact. Den Haag: SCP.

Gilroy, P. (2004), After Empire: Melancholia or Convivial Culture?. Abingdon: Routledge.

Grattet, R. (2009), The urban ecology of bias crime: A study of disorganized and defended neighborhoods, Social Problems, 56(1), 132150 .

Huijink, W. \& J. Dagevos (2015), Inleiding en achtergrond. In: W. Huijnk, J. Dagevos, M. Gijsberts \& I. Andriessen (red.), Werelden van verschil. Over de sociaal-culturele afstand en positie van migrantengroepen in Nederland. Den Haag: SCP, 30-37.

Laan Bouma-Doff, W. van der (2005), De buurt als belemmering? De samenhang tussen etnische concentratie en integratie. Assen: Van Gorcum.

Laan Bouma-Doff, W. van der (2006), Confined Contact. The Consequences of Spatial Isolation of Ethnic Minorities in the Netherlands. Delft: OTB Research Institute for Housing, Urban and Mobility Studies.

Leman, J. (2017), De sociale problematiek in Molenbeek en het gewelddadige jihadisme. Cahiers Politiestudies, 42, 213-236.

Maréchal, B. et al. (2014), Moslims en niet-moslims in Brussel: tussen spanningen en wederzijdse aanpassingen. Brussel: Koning Boudewijnstichting.

May, J. (1996), Globalization and the politics of place and identity in an inner city London neighborhood. Transactions of the Institute of British Geographers, 21(1), 194-215. 
Meissner, F. \& S. Vertovec (2015), Comparing super-diversity. Ethnic and Racial Studies, 38(4), 541-555, DOI:

10.1080/01419870.2015.980295.

Mepschen, P. (2016), The culturalization of everyday life: Autochthony in Amsterdam New West. In: J.W. Duyvendak, P. Geschiere \& E. Tonkens (eds.), The Culturalization of Citizenship. Belonging and Polarization in a Globalizing World. Basingstoke: Palgrave Macmillan, 73-95.

Nowicka, M. \& S. Vertovec (2016), Comparing convivialities: Dreams and relaties of living-with-difference. European Journal of Cultural Studies, $17(4), 341-356$.

Oldenburg, R. (1989), The Great Good Place. New York: Paragon House.

Padilla, B., J. Azevedo \& A. Olmos-Alcaraz (2015), Super-diversity and conviviality: Exploring frameworks for doing ethnography in Southern European intercultural cities. Ethnic and Racial Studies, 38, 621-635.

Park, R.E. \& E.W. Burgess (1925), The City. Chicago: Chicago University Press.

Pemberton, S. \& J. Phillimore (2016), Migrant place-making in superdiverse neighbourhoods: moving beyond ethno-national boundaries. Urban Studies. DOI: 10.1177/0042098016656988.

Phillips, D. (2010), Minority ethnic segregation, integration and citizenship: A European perspective. Journal of Ethnic and Migration Studies, 36(2), 313-332.

Pinkster, F. (2007), Je bent wie je kent? Buurtgebonden sociale contacten, socialisering en sociale mobiliteit in een Haagse achterstandswijk. In: R. van Kempen \& S. Musterd (red.), De stadsbuurt: ontwikkeling en betekenis. Assen: Van Gorcum, 109-120.

Pinkster, F.M. (2014), 'I just live here': Everyday practices of disaffiliation of middle-class households in disadvantaged neighbourhoods. Urban Studies, 51(4), 810-826.

Pinkster, F., M. Permentier \& K. Wittebrood (2014), Moving considerations of middle-class residents in Dutch disadvantaged neighbourhoods: exploring the relationship between disorder and attachment. Environment and Planning A, 46, 2898-2914.

Putnam, R.D. (2007), E Pluribus Unum: Diversity and community in the twenty-first century. Scandinavian Political Studies, 30(2), 137-174.

Reijndorp, A. (2004), Stadswijk. Stedenbouw en dagelijks leven. Rotterdam: Nai uitgevers. 
Den Haag: SCP.

Sennett, R. (1996) (1970), The Uses of Disorder. Personal Identity and City Life. New York: Norton.

Staring, R., F. Geelhoed, G. Aslanoglu, J. Hiah \& M. Kox (2014), Ontwikkelingen in de maatschappelijke positie van Turkse Nederlanders. Risico's op criminaliteit en radicalisering?. Den Haag: Boom Lemma uitgevers.

Sterckx, L. \& B. van der Ent (2015), Met twee maten gemeten. In: W. Huijnk, J. Dagevos, M. Gijsberts \& I. Andriessen (red.), Werelden van verschil. Over de sociaal-culturele afstand en positie van migrantengroepen in Nederland. Den Haag: SCP, 219-277.

Swaaningen, R. van (2017), Waar is de boze witte man?. Online op: www.crimeur.nl/waar-is-de-boze-witte-man .

Stokkom, B. van \& N. Toenders (2010), De sociale cohesie voorbij. Actieve burgers in achterstandswijken. Amsterdam: Pallas.

Sunier, T. \& N. Landman (2014), Turkse islam. Actualisatie van kennis over Turkse religieuze stromingen en organisaties in Nederland. Een literatuurstudie in opdracht van het Ministerie van Sociale Zaken en Werkgelegenheid . Amsterdam: VU Amsterdam.

Suttles, G.D. (1972), The Social Construction of Communities. Chicago: Chicago University Press.

Tersteeg, A. \& F. Pinkster (2016), 'Us up here and them down there': How design, management, and neighborhood facilities shape social distance in a mixed-tenure housing development. Urban Affairs Review, 52(5), 751-779.

Vertovec, S. (2007), Super-diversity and its implications. Ethnic and Racial Studies, 30(6), 1024-1054, DOI: 10.1080/01419870701599465.

Vertovec, S. (ed.) (2015), Diversities old and new. Migration and sociospatial patterns in New York, Singapore and Johannesburg. Basingstoke: Palgrave Macmillan.

Vogel, L. (2016). Working conditions in construction: a paradoxical invisibility. The European Trade Union Institute's (ETUI) health and safety at work magazine, spring-summer 2016: 12-16.

www.etui.org/Topics/Health-Safety-workingconditions/HesaMag/Construction-workers-at-the-mercy-of-socialdumping.

Weltevrede, A.M., J. de Boom, S. Rezai, L. Zuijderwijk \& G. Engbersen (2009), Arbeidsmigranten uit Midden- en Oost-Europa. Een 
Wessendorf, S. (2013), Commonplace diversity and the 'ethos of mixing': perceptions of difference in a London neighbourhood. Identities: Global Studies in Culture and Power, 20(4), 407-422.

Wessendorf, S. (2016), Settling in a super-diverse context: Recent migrants' experiences of conviviality. European Journal of Cultural Studies, 17(4), 449-463.

\section{Noten}

1 Zie ook de discussiebijdrage van Snel en Glas in dit nummer.

2 Zie ook K. Zandbergen, Asscher: 'Integratie is ook loslaten', Trouw, 29 november 2014, www.trouw.nl/home/asscher-integratie-is-ook-loslaten$\sim$ af4aco3e.

3 Voor overzichten zie Duyvendak et al. (2008) en Van Stokkom _ Toenders (2010).

4 Zie European Journal of Cultural Studies 17(4) 2014 en Journal of Intercultural Studies 37(5) 2016.

(C) Boom juridisch 